\title{
A República da Espanha e os republicanos brasileiros na imprensa ilustrada. Rio de Janeiro, 1873.
}

\author{
Republic of Spain and Brazilian republicans in illustrated press. Rio de \\ Janeiro, 1873.
}

\author{
Aristeu Elisandro Machado Lopes*
}

\section{RESUMO}

A campanha republicana no Brasil teve seu início oficial com a fundação do Partido Republicano no Rio de Janeiro em 1870. Logo após o seu surgimento, a imprensa ilustrada que circulava no centro político do Império noticiou e comentou em suas páginas de il ustrações as atividades republicanas. As considerações aos republicanos alcançaram notabilidade no ano de 1873 quando um governo republicano foi proclamado na Espanha substituindo a monarquia. As mudanças políticas no país europeu não passaram despercebidas pelos republicanos brasileiros que comemoraram o novo regime. A imprensa ilustrada aproveitou a situação para tratar do ideário republicano em suas páginas abordando a celebração e a consequente polêmica ocasionada a partir da festa republicana. A proposta deste artigo é analisar as ilustrações de três periódicos: A Vida Fluminense, O Mosquito e Semana Illustrada que trataram da festa organizada pelos republicanos brasileiros para celebrar a República Espanhola. As notícias veiculadas e os desenhos informavam o leitor sobre o que aconteceu durante a celebração sem perder o ponto de vista do humore da irreverência que caracterizava os jornais de ilustrações.

Palavras-chave: Imprensa ilustrada. República. Rio de Janeiro. Espanha. Século XIX

\section{ABSTRACT}

Republican campaign in Brazil was officially started through Republican Party foundation in Rio de Janeiro, 1870. Soon after its emergence, the illustrated press in the political center of the Empire announced and mentioned all the political activities on its pages. Comments on republicans were notorious in 1873, when the Republican government replaced Monarchy in Spain. Political changes in that country did not go unnoticed by Brazilian republicans, who celebrated the new regime. Illustrated press seized the occasion to approach republican ideals by showing celebrations and controversies after republican festivity. This article tries to analyze illustrations in three magazines: A Vida Fluminense, O Mosquito and Semana Illustrada, which approached the party organized by republicans to celebrate Spanish Republic. All news

\footnotetext{
* Doutor em História/UFRGS. Professor Adjunto IV do Departamento e do Programa de Pós-Graduação em História da Universidade Federal de Pelotas/UFPel. E-mail: aristeuufpel@yahoo.com.br
} 
and drawings told readers about the events which took place during festivities, without leaving aside the mood and irreverence tipical to illustrated magazines.

Keyword: Illustrated press. Republic. Rio de Janeiro. XIX Century.

\section{Considerações iniciais}

A imprensa ilustrada no Brasil do século XIX alcançou um desenvolvimento significativo. A cidade do Rio de Janeiro, centro político do Império do Brasil, concentrou a maioria dos periódicos que circularam neste período. Em 1844 o lançamento do periódico Lanterna Mágica demarcou o começo de uma intensa produção de jornais ilustrados (SALGUEIRO, 2003). A partir do final dos anos 1860 e, sobretudo, nas duas décadas seguintes surgiram os primeiros jornais, melhor estruturados, com uma vida longa e com circulação semanal constante. Os jornais se anunciavam como ilustrados e humorísticos destinando suas páginas às mais variadas abordagens da vida imperial brasileira. As notícias e os eventos cotidianos não passavam despercebidos pela percepção atenta do caricaturista que com seu lápis logo apresentava-os aos seus leitores com sua verve satírica. Um dos temas que se destacaram nos periódicos foi a política da época com desenhos que apresentavam, com humor, o Império, o Imperador Dom Pedro II, os partidos políticos e seus representantes ${ }^{1}$.

Nesse conjunto estavam também os republicanos e a sua campanha iniciada no Rio de Janeiro a partir de 1870 com a fundação do Partido Republicano (BOEHRER, 2000). Logo nos primeiros anos de suas atividades, o partido, o jornal de propagação das ideias e seus principais expoentes apareceram nas páginas envolvidos em situações cômicas. Contudo, foi no ano de 1873 que os republicanos alcançaram visibilidade, não apenas entre os habitantes da Corte do Império do Brasil, como também nas páginas da imprensa ilustrada. Neste ano um evento internacional - a Proclamação da República na Espanha após a renúncia do Rei Amadeu $\mathrm{I}^{2}$ - foi comemorado pelos republicanos brasileiros. Na tarde e na noite do dia 27 de fevereiro de 1873 reuniram-se na sede da redação do jornal $A$ Republica os republicanos e os simpatizantes do partido para celebrar a mudança de governo. A confraternização pacífica

\footnotetext{
${ }^{1}$ Os temas políticos também concentravamgrande parte das páginas dos jornais de ilustração produzidos na Europa desde as primeiras décadas do século XIX, os quais eram referências para os brasileiros: "O recurso da ilustração periódica também vinha na esteira de uma voga europeia - aquela dos jornais caricatos que faziam sucesso na Europa. Em particular, na França, onde o talento do caricaturista Honoré Daumier (1808-1879) imprimia em desenho as contradições e ironias da Paris pós-revolução burguesa de 1830" (MARTINS, 2008, p.65).

${ }^{2} \mathrm{O}$ período do regime republicano espanhol foi marcado por divergências entre grupos políticos, que resultaram na alternância de vários presidentes e no fim da experiência republicana na Espanha em 1874, com um golpe de estado que restituiu a Monarquia. Representantes da Dinastia Bourbon - que recuperaria o trono - generais, políticos, banqueiros e homens de negócios e de interesses coloniais contribuíram para o fim da Primeira República Espanhola (VALDEÓN; PEREZ; JULIÁ, 2003, p.399).
} 
acabou em confusão e uma tentativa de empastelamento do jornal. (A Republica, 01/03/1873). $\mathrm{O}$ conflito ainda se estenderia até o dia seguinte quando ocorreu um novo ataque à sede da redação.

Nesse ano circulavam no Rio de Janeiro os periódicos $A$ Vida Fluminense, O Mosquito e Semana Illustrada e as comemorações se transformaram no tema das suas páginas, em março de 1873. Candido de Faria, Angelo Agostini e Henrique Fleiuss eram os artistas que estavam no comando, respectivamente, da produção das imagens desses jornais. Este artigo pretende analisar um conjunto de ilustrações e notícias que trataram da festa promovida pelos republicanos brasileiros em celebração à República proclamada na Espanha. A opinião dos responsáveis pelos periódicos, em relação aos festejos, não foi unânime da mesma forma que também não era em relação à política do tempo. A Semana Illustrada nutria uma tendência monarquista, $A$ Vida Fluminense não apresentou simpatias ao Império e também não se caracterizava como um periódico filiado a partidos políticos; a política da época era tomada de uma forma genérica e, quase sempre, em tom de sátira. Já $O$ Mosquito afirmava que iria "ocupar-se de política", mas seria uma política "sem bandeira, sem compromissos, sem compadrescos, sem rolha" (O Mosquito, 02/09/1871).

O relevante é averiguar esses periódicos não como um espelho da realidade, mas "como espaço de representação do real, ou melhor, de momentos particulares da realidade" (CAPELATO, 1988, p.24). Dessa forma, é fundamental analisar os periódicos superando a

perspectiva limitada de identificar a imprensa como portadora dos 'fatos' e da 'verdade'. Deixaram-se também para trás posturas preconcebidas, que a interpretavam, desdenhosamente, como mero veículo de ideias ou forças sociais (NEVES; MOREL; FERREIRA, 2006, p.10).

A partir destas considerações, a análise desenvolvida neste artigo, com os textos e as ilustrações dos jornais de humor do Rio de Janeiro, deve ponderar quais as opiniões publicadas sobre as questões políticas - e em especial sobre a republicana. Igualmente, deve identificar quem eram os artistas responsáveis pelos desenhos e como a festa dos republicanos foi desenhada e difundida nas páginas dos periódicos. A análise das posições dos periódicos sobre o comportamento dos republicanos e a festa promovida à Proclamação da República Espanhola possibilitou compreender que, sobre este tema, manifestaram opiniões distintas. 
Dessa maneira, ao analisar a produção artística veiculada nas páginas dos periódicos, deve-se também levar em consideração qual a posição dos artistas que era reproduzida através de seus desenhos. Para isso, igualmente importante que, associado à análise da imagem, a parte textual também seja valorizada. Os artigos e as notícias permitem entender, na maioria das vezes, o que aqueles periódicos compreendiam em relação à política do tempo e como esses posicionamentos eram publicizados. Da mesma forma, as legendas que acompanham as imagens são relevantes, já que esse era o recurso encontrado pelos artistas para narrar a ação que se passava no desenho. Imagens e textos se intercalam, se complementam e colaboram com o leitor e o historiador de uma outra época, a fim de que compreendam as posições dos jornalistas e desenhistas sobre as questões políticas do passado.

\section{A Vida Fluminense e as doutrinas contrárias}

$A$ Vida Fluminense (1868-1875) foi um jornal de crítica que se intitulava "folha joco-séria ilustrada" e que publicava "revistas, caricaturas, retratos, modas, vistas, músicas, etc, etc" ( $A$ Vida Fluminense, 01/01/1868). Nas páginas destinadas à parte escrita, o assunto de maior relevância foi a atividade teatral da Corte. Crônicas como a intitulada "Assuntos de várias cores" tomavam uma grande parte do jornal, geralmente iniciando na terceira página e se estendendo até a sétima ou oitava.

Os temas políticos apareciam nas duas primeiras páginas do jornal. Um dos assuntos amplamente divulgados foi a Guerra do Paraguai (1864-1870). Os leitores eram informados não apenas sobre os acontecimentos e os avanços dos aliados na guerra como também a eles eram oferecidos desenhos dos mapas das operações militares, de membros de grande destaque do exército e caricaturas satirizando os inimigos (TORAL, 2001). Participaram da parte ilustrada de $A$ Vida Fluminense Angelo Agostini, Antonio Alves do Vale de Sousa Pinto, Candido Aragonês de Faria e Luigi Borgomainerio (LIMA, 1963, p.101).

O periódico publicou notícias sobre os festejos promovidos pelos republicanos criticando as suas atitudes. No texto, seu autor, identificado somente com a letra $\mathrm{Z}$, destacava que a semana fora tomada por dois assuntos principais: o carnaval e o jornal $A$ Republica. A crítica aos republicanos iniciava salientando que o Brasil era um país livre: "Cada um aqui faz o que quer e o que lhe vem a cabeça, desrespeita as leis, escarnece das autoridades" ( $A$ Vida 
Fluminense, 01/03/1873) ${ }^{3}$. Na continuação era ressaltada uma postura um tanto pejorativa do periódico em relação não só ao jornal como aos republicanos:

\begin{abstract}
A existência de uma folha diária e de uma tabuleta, ambas com o título de - Republica - a propaganda de doutrinas contrárias aquelas pelas quais o país se rege e a virulência com que se atacam as instituições vigentes, são provas irrefutáveis do que acima fica expedido. Apelo para a consciência dos nossos poucos republicanos - eles que digam, se em outro qualquer país se tolera o que por ai vemos a cada passo e se permitem as cenas de que foi teatro a rua do Ouvidor na tarde e noite de 27 de fevereiro.
\end{abstract}

A posição de $A$ Vida é contrária não apenas ao conflito que resultou no ataque à redação do jornal, como também aos caminhos que lhe proporcionaram. Na visão do articulista a "liberdade" gozada no Brasil foi o que possibilitou aos republicanos organizarem uma festa para comemorar a Proclamação da República da Espanha, desrespeitando, assim, a Monarquia Brasileira.

Ao noticiar a desordem ocorrida naquela noite, o texto revela uma posição antipática aos republicanos, ao destacar que eles propagavam doutrinas contrárias àquelas pelas quais o país era regido, incitando ataques às instituições estabelecidas. No final desta citação, na passagem que trata das "cenas de que foi teatro a rua do ouvidor", ou seja, a sede da redação da folha republicana, o texto não criticava os conflitos ocasionados com a reunião pública republicana e sim recriminava a própria reunião, salientando que a confusão foi uma decorrência da sua realização. As cenas que se passaram no teatro em que se transformou a rua do Ouvidor não eram, portanto, o apedrejamento do jornal e sim a festa imprópria promovida por seus redatores.

Na sequência da matéria, assinalava que a Proclamação da República na Espanha foi uma catástrofe e os redatores aproveitaram-na para "romper em manifestações ruidosas" e realizaram "discursos com alusões um pouco fortes" e, "a troco de alguns vinténs, obrigou a banda alemã a tocar a marselhesa". Esses foram os motivos que levaram o povo que se aglomerava para acompanhar os festejos a irromperem contra as atitudes republicanas, levando-os aos atos de vandalismo. Contudo, uma bandeira colocada na fachada do prédio republicano foi o ápice que possibilitou o quebra-quebra:

\footnotetext{
${ }^{3}$ A grafia de todas as citações dos jornais foi atualizada.
} 
A porta do estabelecimento, onde pouco a pouco foi se aglomerando o povo, indiferente ao princípio, exaltado mais tarde quando, por entre as bandeiras desfraldadas, deu com a brasileira... arranjada lá ao modo republicano. (grifo do jornal)

Na visão do jornal $A$ Republica esses atos tiveram outra origem e não estavam relacionados ao povo que assistia o acontecimento conforme divulgado pelo partido num manifesto lançado em março de $1873^{4}$. Neste, esclareciam que o comício em homenagem à República Espanhola, realizado na sede do jornal, tinha recebido permissão da polícia e que os republicanos participantes iriam proceder conforme as ordens impostas pela polícia. À realização da celebração, o prédio do jornal foi ornamentado com várias bandeiras de nações republicanas e no lugar da bandeira nacional colocaram "uma bandeira com as cores nacionais, sem símbolos, sem qualquer dístico ou distintivo que pudesse ferir a susceptibilidade de quem quer que fosse". Quando o evento iniciou, o povo começou a se aglomerar nas imediações do prédio e os pedidos de ordem feitos pelos republicanos foram aceitos por todos os presentes.

A situação mudou quando Quintino Bocaiúva tentou discursar, sendo interrompido por gritos de vivas a Monarquia vindos não do povo, que pedia ordem e silêncio para ouvi-lo, mas de um grupo de capangas que eram conduzidos por dois filhos de um senador que não foi identificado no manifesto. Após os discursos de Quintino Bocaiúva e do redator do jornal Francisco Cunha a população se dispersou, menos a turba, comandada pelos filhos do senador, que se aproximou do prédio e começou a atirar pedras nas janelas. Os republicanos pediram a proteção da polícia, mas foi em vão. $\mathrm{O}$ ataque durou cerca de duas horas e contabilizou a destruição das várias bandeiras hasteadas e a quebra do retrato de Emilio Castellar, um dos responsáveis pela proclamação da República Espanhola. No dia seguinte, informações desencontradas chegavam à redação informando que o mesmo grupo retornaria para dar continuidade ao ataque. $O$ manifesto não informa se foi o mesmo grupo, mas novamente o prédio foi vandalizado:

Imediatamente grupos suspeitos começaram a aparecer. Forças consideráveis, como na véspera, foram postadas no arsenal da marinha, na escola central, nas praças e ruas adjacentes à Republica (...) Logo após gritos sinistros e impropérios de toda ordem se fizeram ouvir. Morra a Republica! Morram os republicanos! Fora a canalha! O povo que se foi reunindo conservou-se calmo e silencioso, ocupando lugar distinto dos

\footnotetext{
${ }^{4}$ A sequência dos três parágrafos foi escrita baseada no manifesto publicado em A Republica 01/03/1873.
} 
amotinadores. Os nossos amigos enchiam as varandas do edifício, presenciando com serenidade o espetáculo. Os gritos continuaram até que se aproximou a força policial. Pareceu ser o sinal convencionado. Uma nuvem de projéteis cobriu a varanda penetrando dentro da sala da redação. Fecharam-se as janelas. Seguiu-se, então, o bombardeamento.

Logo após os primeiros ataques, os amotinados se dispersaram quando novas patrulhas da polícia chegaram. Para os redatores do manifesto havia uma combinação entre a polícia e os que promoviam o ataque: eles poderiam realizar seus atos no intervalo entre a chegada da primeira e da segunda força policial quando, então, deveriam se dispersar. No final do manifesto, assinado pelos redatores do jornal, era comunicada a interrupção das atividades jornalísticas, que posteriormente seriam recolocadas em funcionamento. Na sequência, apresentavam a ata da reunião do Partido Republicano na qual relatavam e repudiavam os atos de agressão sofridos pela redação do jornal. A ata foi assinada por mais de oitenta correligionários.

Enquanto o jornal não retomava a normalidade da sua circulação, boletins foram lançados nos quais se explicava a posição dos redatores: "O Boletim republicano é o produto natural da situação anárquica e violenta criada pelo governo. Assim o querem assim o tenham. A Republica era um órgão de propaganda pacífica. O Boletim é um grito de indignação"(A Republica, 03/03/1873). A polêmica gerada com a festa republicana retornaria a $A$ Vida Fluminense na edição do dia 08 de março de 1873. O periódico, aproveitando-se da situação do jornal republicano, satirizava os seus simpatizantes narrando, com expectativa, o retorno da folha. Praticamente todo o número publicado neste dia foi dedicado à situação dos republicanos com desenhos confeccionados por Candido José Aragonês de Faria (1817-1911), que assinava suas produções apenas como Faria ${ }^{5}$. O desenho apresentava uma alegoria feminina representando o jornal conversando com outra alegoria que remetia ao jornal $A$ Reforma. (Figura 1)

A legenda do desenho evidencia o tom irônico do jornal ao tratar do conflito: "Ora veja vizinha em que estado me puseram a louça! Pratos, xícaras e pires... Tudo...Tudo levou a breca!

\footnotetext{
${ }^{5}$ Nascido em 1849 em Laranjeiras na então Província de Sergipe Del Rey, mudou-se, após o falecimento do pai coma família para o Rio de Janeiro. Iniciou suas atividades artísticas no periódico A Pacotilha em 1866. Faria foi aluno da Academia Imperial de Belas Artes, AIBA, fundada em 1816, e que iniciou seus trabalhos de ensino oficialmente em 1826 (MORAIS, 1995, p.11). Ele ingressou em meados dos anos 1860. Fundou e participou de vários periódicos que circularam no Rio de Janeiro como, entre outros $A$ Vida Fluminense, O Mephistópheles e OMosquito. Alcançaria maior notoriedade ao deixar a Corte em1878. Após uma passada por Porto Alegre, capital da Província do Rio Grande do Sul, elançando ali O Figaro (FERREIRA, 1964, p.62-63), mudou-se para Buenos Aires colaborando como periódico El Mosquito por três anos e em 1880 no periódico La Cotorra (TELLES, 2007, p.36). Mais tarde foi para Paris e estabeleceu um ateliê alcançando sucesso com ilustrações de livros e partituras. Outro ramo da litografia explorado pelo artista na capital francesa foi o desenvolvimento de cartazes publicitários com anúncios de espetáculos teatrais, concertos e circos e no início do século XX obteve sucesso com cartazes para o cinema. Disponível em < http://cinema.encyclopedie.personnalites.bifi.fr/index.php?pl=29345 $>$ Acesso em 04/10/2016.
} 
Tomara eu que me fizessem outro tanto... porque veriam... veriam se eu sou para graças!...”. A louça quebrada era uma referência a tipografia do jornal, a qual poderia ter ficado avariada com os atos de vandalismo praticados contra a sede durante os tumultos. Neto ressalta que o ato de empastelar um jornal significava invadir e destruir o jornal, sobretudo os tipos móveis que eram usados na confecção da montagem dos textos:

Empastelar, nesse caso, significava abrir as gavetas de tipos e esparramar as letras de chumbo no chão, o que exigia meses para reorganizá-las. Com o tempo, o vocábulo passou a designar qualquer ato de violência contra jornais. (NETO, 2013, p.21-22).

Provavelmente os tipos de $A$ Republica não foram esparramados, já que não houve uma invasão ao prédio, mas o ataque com pedras, projeteis e outros objetos e a movimentação daqueles que estavam no interior do prédio que procuravam abrigo podem ter danificado ou espalhado algumas caixas de tipos.

Os redatores do jornal $A$ Republica encontraram apoio de outros congêneres, sobretudo do jornal $A$ Reforma que defendeu a folha republicana, condenou os atos de violência e transcreveu na íntegra o manifesto divulgado pelos republicanos. Justificavam a transcrição asseverando que

O Manifesto é tão calmo quanto digno, e neste momento em que vemos cessar a publicação de um jornal, garroteado pelos esbirros do poder, não temos senão palavras de felicitação aos ilustres redatores da Republica, que sempre mantiveram o órgão do seu partido na altura de uma imprensa ilustrada e séria ( $A$ Reforma, 02/03/1873). 


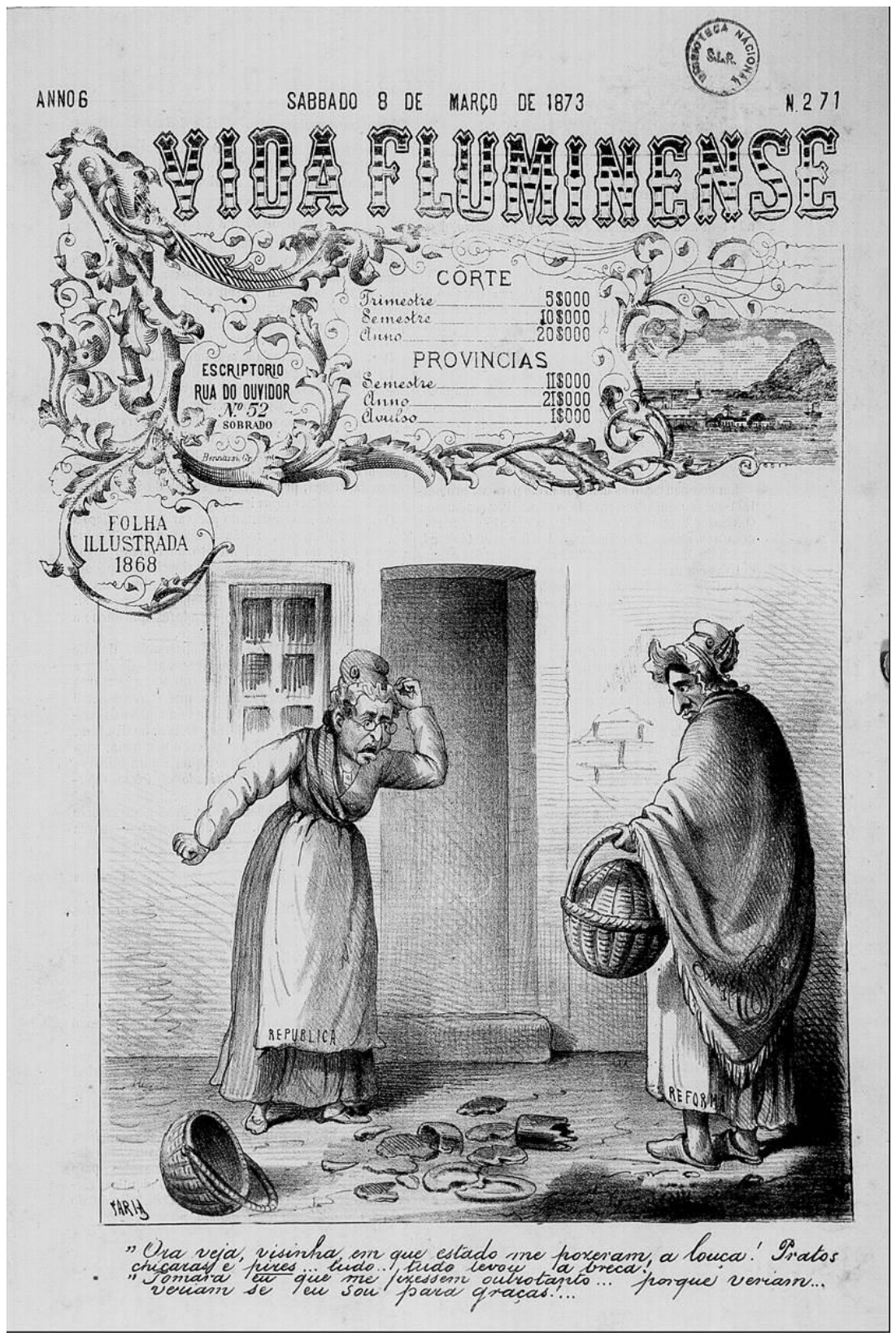

Figura 1: A Republica e as louças quebradas

Legendas: Ora veja vizinha em que estado me puseram a louça! Pratos, xícaras e pires... Tudo...Tudo levou a breca! Tomara eu que me fizessem outro tanto... porque veriam... veriam se eu sou para graças!...”.

Fonte: A Vida Fluminense, Rio de Janeiro, n.271, p.1323, 08 mar. 1873. Acervo: Hemeroteca Digital-Biblioteca Nacional.

A ilustração reforça os vínculos entre os dois jornais colocando-os como duas mulheres vizinhas. A relação não foi feita apenas pela localização geográfica dos dois jornais - ambos com as sedes de suas redações na Rua do Ouvidor, A Republica no número 132 e A Reforma no número 148 - como também pela aproximação das causas que defendiam. O jornal $A$ Reforma 
foi fundado em 1869 por membros do Centro Liberal formado por liberais que pretendiam revitalizar o partido (CARVALHO, 2007, p.24). Contudo, a revitalização pretendida sugeria mudanças significativas, tanto no partido, como na própria administração do país. No mesmo mês de sua fundação, o Centro lançou um manifesto e um novo programa para o partido. $O$ manifesto encerrava com a seguinte premissa: "Ou a reforma, ou a revolução; a reforma para conjurar a revolução” (CARVALHO, 2007, p.24). Dessa forma, os ideais reformadores defendidos nas páginas do jornal foram, constantemente, associados com aqueles dos republicanos pelos jornais ilustrados. O desenho veiculado na $A$ Vida Fluminense remete a essa associação ${ }^{6}$.

Nas páginas centrais, $A$ Vida Fluminense continuou abordando a festa republicana. Os vários desenhos, intitulados "Republicanices" recriavam parte dos conflitos. (figura 2) Um dos desenhos fazia referência, justamente, à mudança política ocorrida na Espanha. Em uma mesa, acontece um jogo de pôquer; de um lado está uma figura alegórica masculina, com um manto e uma coroa, simbolizando a Monarquia, e do outro lado da mesa está uma alegoria feminina da República. A alegoria foi desenhada com uma expressão de irritabilidade, possivelmente pela atitude do seu adversário que, mesmo concedendo uma de suas cartas, identificada como Amadeu, ou seja, o rei espanhol que abdicara, assegurava que ainda tinha várias outras na mão, em uma alusão as demais monarquias européias.

A ilustração de Candido de Faria assinalava na legenda que "Desta consegue eu descartarme. E as outras que tenho cá na mão? (a cena passa-se na Europa)". Acompanha os jogadores, Emilio Castelar, o qual, feliz, apontava para a figura da República, como se estivesse indicand o o caminho que a Espanha seguiria a partir daquele momento. Atrás, um general com os braços cruzados apenas observava a cena.

Na sequência, os desenhos remetiam aos republicanos brasileiros e aos acontecimentos ocorridos na redação da folha republicana. Em sentido horário: Quintino Bocaiuva e outro correligionário republicano sendo atacados com pedras na sacada do prédio da redação; no outro desenho, aparece o retrato de Castelar e um dos republicanos está pendurado na varanda; um adversário comemorando o ataque; a dispersão do povo que assistia e dos músicos da banda; Quintino conversa com outro republicano confessando que foram responsáveis pela "nossa própria desgraça" e os dois estão chorando; a tentativa de invasão à sede do jornal no segundo dia - relatada no manifesto dos republicanos. Por fim, as "vantagens da democracia" sobre a comida servida na festa. O primeiro desenho se referia ao possível ataque do "povo". Nele, dois republicanos recomendam a um escravo que caso o

\footnotetext{
${ }^{6}$ No ano de 1868 o Imperador Dom Pedro II demitiu Zacarias de Góis, Presidente do Conselho de Ministros do Império, que era oriundo do Partido Liberal e para assumir seu lugar chamou Joaquim José Rodrigues Torres, o Visconde de Itaboraí, do Partido Conservador. A queda do Gabinete Zacarias provocou manifestação e descontentamento entre os liberais. Ainda neste ano fundaram o Clube Radical e o grupo que estava associado a ele fundaria, em seguida, o jornal $A$ Reforma. Os liberais, então, se dividiram em duas alas, uma formada por radicais e a outra por moderados (COSTA, 2007, p.481).
} 
"povo cá entrar" ele deveria responder que "não estamos em casa". Caso assim procedesse, o escravo seria alforriado.

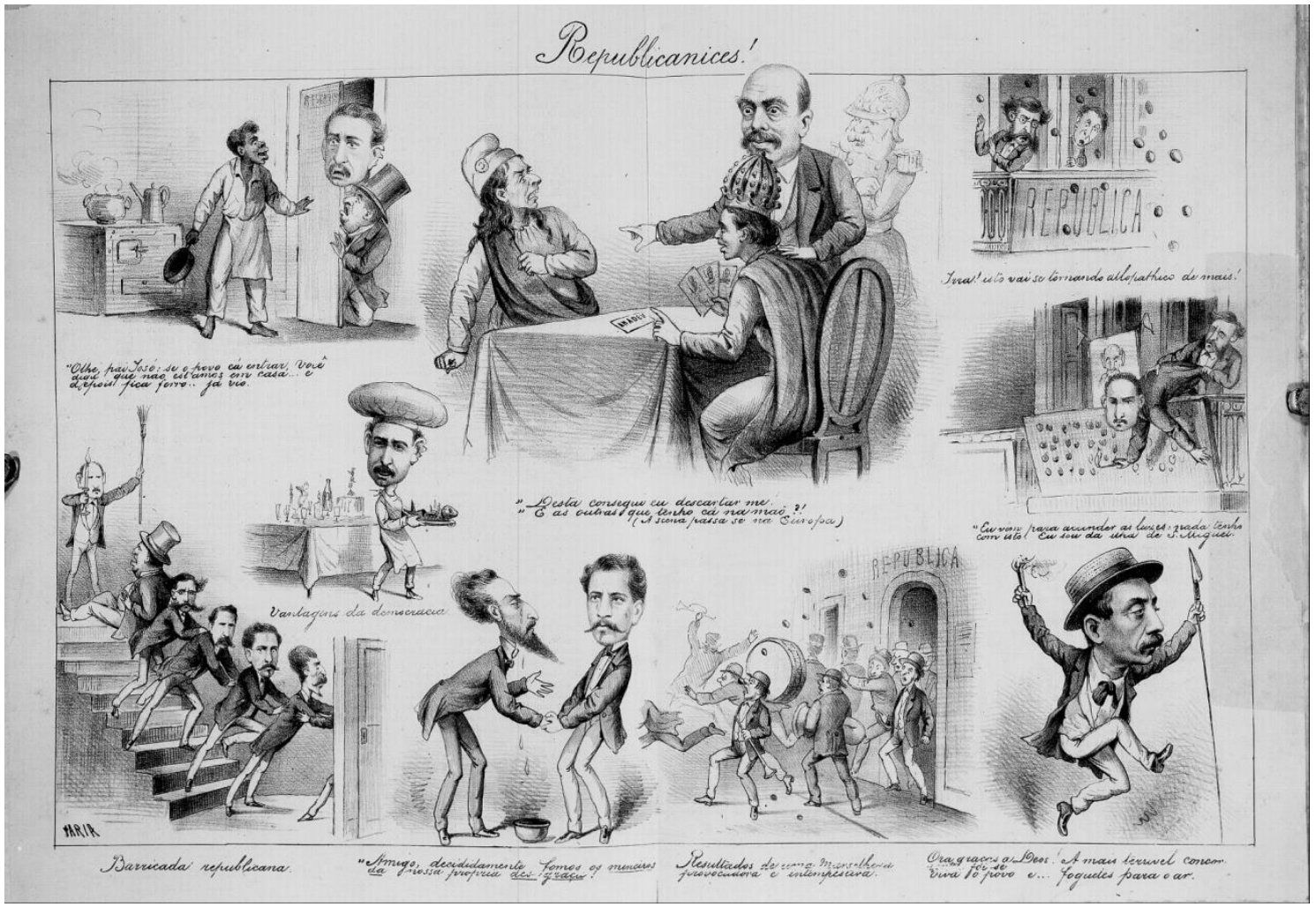

Figura 2: Republicanices

Fonte: A Vida Fluminense, Rio de Janeiro, n.271, p.1326 e 1327, 08 mar. 1873. Acervo: Hemeroteca Digital-Biblioteca Nacional.

A alegoria feminina da República que apareceu nestes desenhos retornaria nas páginas do periódico para novamente criticar os republicanos. A alegoria empregada por Faria é uma clara referência àquelas oriundas a partir da Revolução Francesa e, sobretudo, com o ideário republicano francês desenvolvido no século XIX (AGULHON, 1989). O uso das alegorias foi empregado não apenas entre os caricaturistas na França, como também pelas artes - sendo a tela $A$ Liberdade guiando o povo, de Eugène Delacroix, que mostra uma cena de barricada durante a Revolução de 1830, uma das produções mais conhecidas e difundidas. As alegorias, igualmente, foram muito utilizadas em estátuas e monumentos, constituindo aquilo que ficou conhecido como statuomanie (estatuamania), ou seja, a proliferação de estátuas, bustos, alto relevos, fontes, entre outros produzidos ao longo de todo o século XIX na França (AGULHON, 1988, p.138-140). Nas ilustrações do dia 15 de março de 1873 a alegoria feminina da República retornava às páginas do periódico. Desta vez ela surgia de uma maneira bastante peculiar e acompanhada por Quintino Bocaiúva. (Figura 3) 


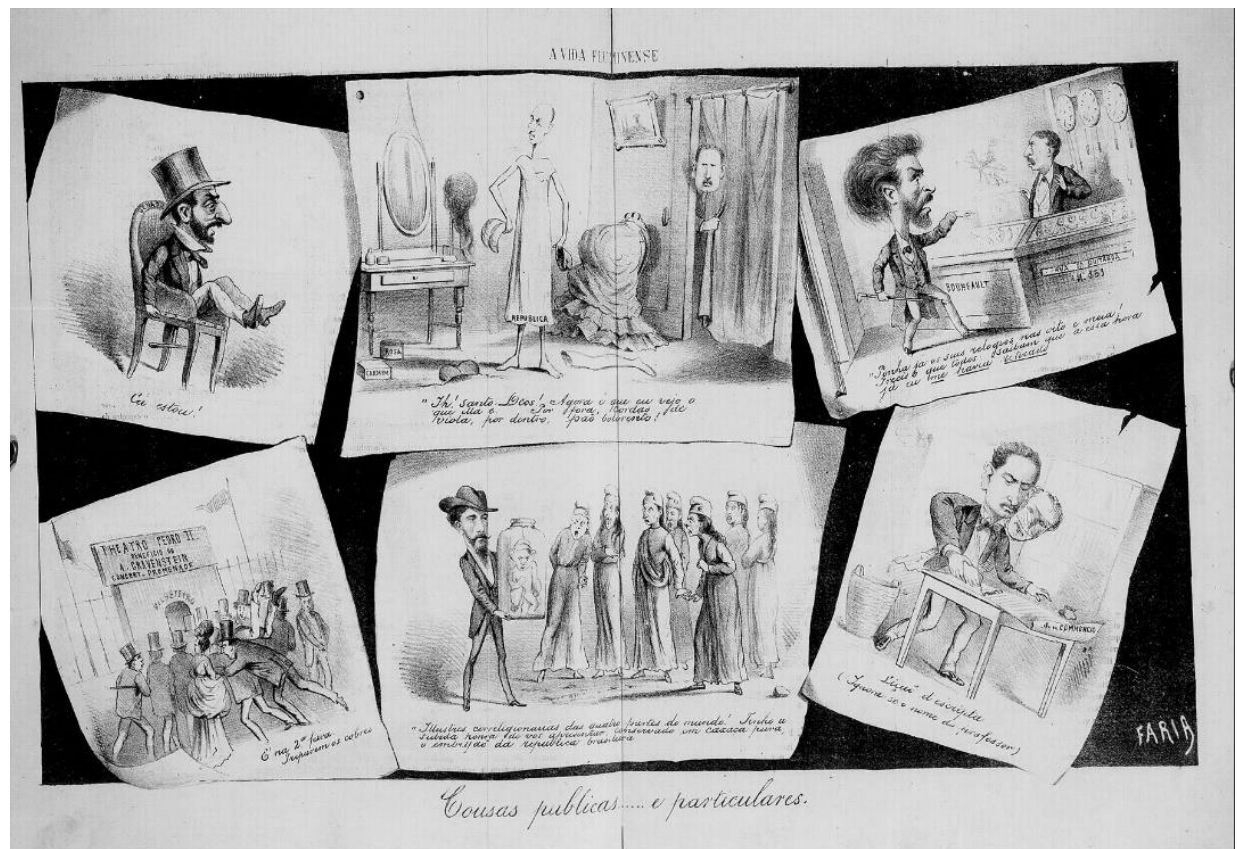

Figura 03: A alegoria despida e o embrião da República Brasileira

Legendas: Ih! Santo Deus! Agora é que eu vejo o que ela é. Por fora, cordas de violão, por dentro, pão bolorento! / Ilustres correligionárias dos quatro partes do mundo! Tenho a súbita honra de vos apresentar, conservado em cachaça pura, o embrião da República brasileira.

Fonte: A Vida Fluminense, Rio de Janeiro, n.272, p.1334 e 1335, 15 mar. 1873. Acervo: Hemeroteca Digital-Biblioteca Nacional.

A comparação com uma mulher se arrumando ou se desarrumando, visto que a imagem não deixava claro o que se passava na cena, servia ao jornal para satirizar a folha republicana. $\mathrm{Na}$ assimilação consideravam que o conteúdo que era publicado pelo jornal dos republicanos, direcionado ao público, tinha algo de falsidade da mesma forma que algumas senhoras quando saíam de suas casas.

Na ilustração aparecem vários objetos de uso feminino como a peruca recostada na penteadeira, caixas de "carmim" e "rosa" no chão e a saia já armada com a anquinha. Espiando por uma porta está um homem, admirado e surpreso, com o que está vendo; a legenda revela o seu pensamento: "Ih! Santo Deus! Agora é que eu vejo o que ela é. Por fora, cordas de violão, por dentro, pão bolorento!". Ainda nessas páginas outros assuntos foram abordados ${ }^{7}$ e a temática republicana mereceu outra ilustração. Na imagem, Quintino Bocaiúva aparece interagindo com outras alegorias femininas da República; ele apresenta a elas o embrião da República Brasileira, conservado em um frasco. As sete alegorias têm expressões diversas e todas estão admiradas com o que lhes é mostrado por Quintino Bocaiúva. A legenda apresenta

\footnotetext{
${ }^{7}$ As duas páginas de ilustrações deste número lembram um quadro e os desenhos de Faria foram confeccionados como se fossem pedaços de papel, afixados nesse quadro. Optou-se por apresentar as duas páginas na íntegra para não perder o efeito esperado pelo caricaturista. No entanto, somente as transcrições das legendas dos dois desenhos foram reproduzidas.
} 
a fala do jornalista: "Ilustres correligionárias das quatro partes do mundo! Tenho a súbita honra de vos apresentar, conservado em cachaça pura, o embrião da república brasileira".

A primeira imagem escarnecia o conteúdo veiculado no jornal republicano, acusando-o de ser algo falso ou, ainda, fantasioso. A segunda imagem satirizava o período em que o jornal estava suspenso e se reorganizando, ficando "em conserva" para voltar à circulação após os ataques à sua redação, o que ocorreu em 15 de abrilde1873. Por outro lado, a ilustração também poderia ser uma referência à atitude daqueles contrários à ideia republicana. No ponto de vista defendido pelos republicanos, em seu o manifesto, os atentados não partiram da totalidade do povo que acompanhava a festa na frente da sede do jornal. Já na matéria veiculada em $A$ Vida era atestado que o tumulto foi ocasionado pelo povo, indiferente ao princípio e em seguida exaltado. $O$ periódico demonstrava em suas páginas a insatisfação do povo com a festa republicana e, diferente do que ocorreu na Espanha, a República no Brasil ainda era um assunto embrionário e em conserva.

Os ânimos do povo se exaltaram devido à utilização de uma bandeira brasileira ao modo republicano. Conforme Ciro Silva, os ataques de "monarquistas exaltados" ocorridos nas noites dos dias 27 e 28 de fevereiro, à sede do jornal, foram o ponto culminante de um processo que se estendia desde o início da circulação do jornal "devido à forma intrépida e arrojada com que se conduzia no combate ao regime vigente" (SILVA, 1983, p. 29). No entanto, quem eram esses monarquistas exaltados? Ciro Silva não revela, A Vida Fluminense considerava que o próprio jornal, ao propagar "doutrinas contrárias", acabou insuflando o povo. No manifesto dos republicanos era reportado que apenas uma parcela daqueles que assistiam se sublevou, apoiada ou acobertada pela polícia. Esta percepção defendida pelos republicanos, que identifica quem eram os "monarquistas exaltados", foi verificada em $O$ Mosquito.

\section{O Mosquito e a patriotada policial}

O Mosquito (1869-1877) foi fundado por Candido Aragonês de Faria ${ }^{8}$ e contou ainda com outros caricaturistas em diversos momentos: Pinheiro Guimarães, Flumen Junius, Antonio

\footnotetext{
${ }^{8}$ O Mosquito, ao longo dos anos que circulou, incorporou os periódicos Comédia Social, O Lobishomem e OMefistófeles (LIMA, 1963, p.104). Este último foi fundado também por Faria em 1874 e por ele inteiramente ilustrado pelos cerca dos dois anos de circulação. Assim, Faria retornava à empresa do jornal fundado por ele anos antes. Essa situação evidencia a circulação de caricaturistas entre os periódicos e também que olançamento deumjornal por um deles não era garantia para alcançar o sucesso almejado. Essa parece ser a situação de Candido Aragonês de Faria, já que em 1873 ele estava no comando das ilustrações do periódico A Vida Fluminense.
} 
Augusto do Vale, Angelo Agostini e Rafael Bordallo Pinheiro. O Mosquito apresentava-se como “jornal caricato e crítico" e, conforme sua apresentação tinha por objetivo

Beliscar, sutilmente, a humanidade; enterrar mesmo o ferrão em certos preconceitos e alusões da nossa sociedade sem deixar calombo ou comichão, é essa a missão deste pequeno filho do Adão mosquital da criação (O Mosquito, 19/09/1869).

Um dos temas políticos do tempo, que ganhou grande relevo por parte dos caricaturistas desta folha, foi o conflito entre a Coroa e a Igreja Católica que culminou na prisão dos bispos de Olinda e Pará. A Questão Religiosa ocupou várias páginas do jornal com caricaturas que ridicularizam os bispos e a igreja e artigos de críticas ferrenhas direcionadas às relações entre o governo e a religião (LIMA, 1963) (BALABAN, 2009).

Se os políticos do tempo, e até mesmo o chefe do Império, eram satirizados, os republicanos não escapavam do lápis afiado dos caricaturistas; na mesma frequência em que os republicanos propagavam sua campanha eles eram referenciados no periódico. Os acontecimentos ocorridos na sede do jornal republicano, portanto, não passaram despercebidos pelo periódico. A análise de um dos textos de $O$ Mosquito aponta que no lugar dos "monarquistas exaltados", conforme aponta Ciro Silva, havia outros tipos de manifestantes, o que parece ser mais coerente para se entender as razões da investida contra a sede do jornal. $O$ Mosquito apresentou um arranjo diferente daquele publicado em $A$ Vida Fluminense posicionando-se a favor dos republicanos, defendendo o povo que somente assistia à festividade e denunciando que no lugar dos verdadeiros baderneiros estavam ações da polícia.

O artigo foi escrito direcionado ao Imperador Dom Pedro II: "Aos reis deve-se a verdade. Dirigimo-nos, pois, a V. M. para lhe dizer a verdade" (O Mosquito, 08/03/1873). A Proclamação da República espanhola, chamada de catástrofe por $A$ Vida Fluminense, foi apontada pelo $O$ Mosquito como uma resolução nobre e cavalheira adotada pelas cortes espanholas que "entenderam que só a forma republicana podia evitar a anarquia". O artigo salientava que Dom Pedro II era conhecedor desses fatos e também que ele não ignorava que no Brasil "há numerosos cidadãos afetos a causa republicana. A estes era natural que a notícia daquela grande conquista enchesse de alvoroço". $\mathrm{O}$ artigo se posiciona a favor da festa republicana e defende o povo que assistia pacificamente a celebração, traçando uma crítica à polícia que, monarquista, improvisou um "povo" para atacar o jornal: 
O sr. Chefe [da polícia] enganara-se. Contava com o povo. O povo veio, viu e nada achou de extraordinário em estarem os músicos alemães a tocar a Marselhesa. Não lhe pareceu miraculoso haver na redação da Republica o letreiro Viva a República. Achou temporã a bandeira da República Brasileira, sabendo que V. M. é o chefe do país, e riu o povo. Riu, mas decentemente. Mas não fez os protestos com que contava o Sr. Ludghero 9 . O povo respeita-se. O povo não é compadre de esbirros. (...) Quando o Sr. Ludghero viu que o povo o não ajudava a proporcionar a V. M. uma ovação monarquista, só achou uma saída para não falhar o espetáculo. Improvisou um "povo" com a flor da minha gente que encontrou a mão. (grifos do jornal)

Conforme o jornal foi este "povo" que atacou atirando pedras e não aquele que apenas estava acompanhando a comemoração. Assim, o artigo denunciava a omissão da polícia em socorrer os republicanos o que vai ao encontro do manifesto publicado em $A$ Republica. $\mathrm{O}$ artigo pode ser visto como simpático aos republicanos se comparado com aquele veiculado em $A$ Vida Fluminense. Ele adquiriu essa característica ao se posicionar contrário às atitudes que resultaram na depredação da sede do jornal, denunciando que os agressores foram alicerçados pela polícia (não se tratava, em sua totalidade, de monarquistas exaltados!); também pode ser visto como simpático ao considerar que a festa promovida pelos republicanos não era uma ação que poderia abalar as estruturas do Império brasileiro e sim, apenas, uma comemoração à instalação de mais um governo republicano.

$\mathrm{O}$ artigo findava informando ao Imperador que a atitude da polícia surtiu um efeito contrário, uma vez que os jornais da Corte, a Câmara dos Deputados e o Senado ocupa ram-se em discutir o ocorrido, o que acabou dando uma maior divulgação aos republicanos:

A República, até ontem tolerada, torna-se ideia perseguida, e os indecisos, os que guardavam para si suas aspirações republicanas, os que esperavam tempos melhores para se declararem, vem dar o público testemunho da sua adesão ao novo partido. (grifos do jornal)

O jornal parecia fazer com essa consideração uma previsão do que estava por vir nos rumos da política brasileira, apontando ao Imperador que o Partido Republicano estava consolidado e que os efeitos ocorridos na noite do dia 27 somente contribuíram para o fortalecimento da causa republicana.

\footnotetext{
${ }^{9}$ Ludghero Gonçalves da Silva, chefe da polícia da Corte. Conforme: (BOEHRER, 2000, p.53).
} 
O mesmo exemplar que veiculou esse artigo, apresentou na primeira página um desenho que, ao contrário daqueles analisados em $A$ Vida Fluminense e daqueles que adiante serão averiguados na Semana Illustrada, não apresentava alegorias femininas e nem os republicanos, mas sim o "povo" responsável pela depredação da sede do jornal e o Sr. Ludghero Gonçalves da Silva, chefe da polícia da Corte. (figura 4) Na ilustração, desenhada por Angelo Agostini ${ }^{10}$, o chefe da polícia está sentado, ao seu lado uma mesa com várias moedas empilhadas. Quatro homens completam o quadro. Eles estão ali para receber pelo "trabalho" desempenhado, ou seja, provocar a confusão durante a festa republicana. A legenda da imagem elucida essa situação e colabora para identificar quem eram os "monarquistas exaltados" e a posição da polícia.

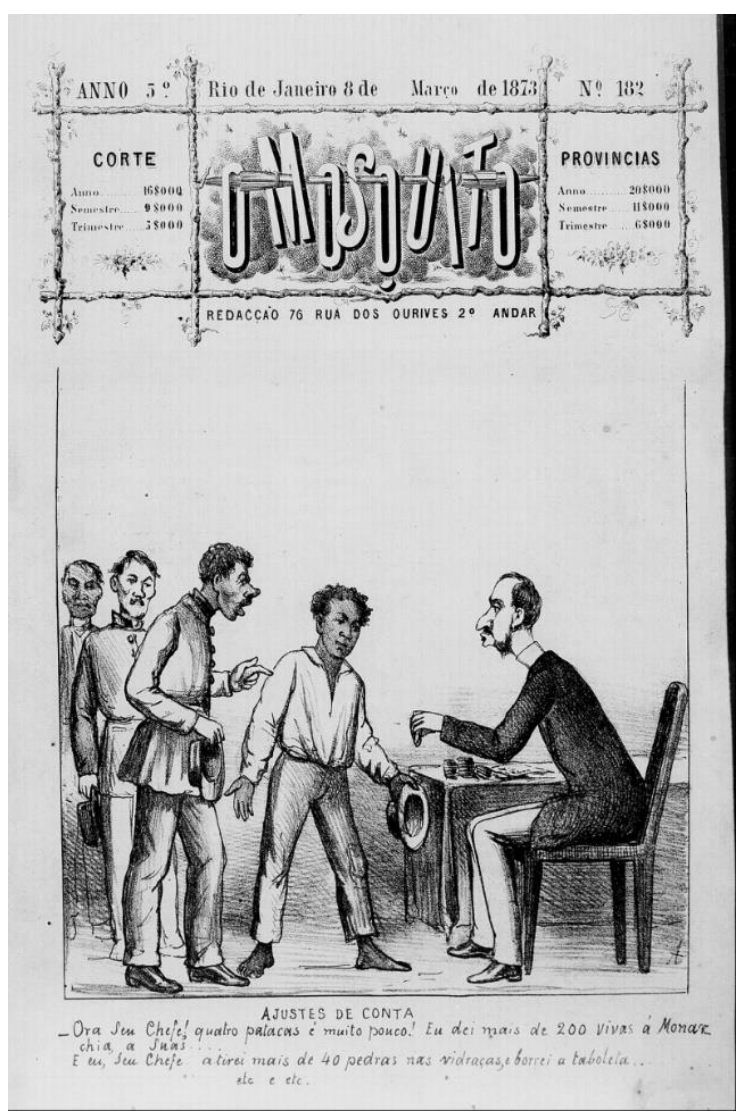

Figura 4: Ajustes de conta

Legenda: Ora seu Chefe! Quatro patacas émuito pouco! Eu dei mais de 200 vivas à Monarquia, a suas...

$\mathrm{E}$ eu, chefe, atirei mais de 40 pedras nas vidraças, e borrei a tabuleta... etc e etc. Fonte: $O$ Mosquito, Rio de Janeiro, n.182, p.1, 08 mar. 1873. Acervo: Hemeroteca Digital-Biblioteca Nacional.

\footnotetext{
${ }^{10}$ Angelo Agostini (1843-1910) nasceu na Itália e aos nove anos foi levado para Paris, cidade na qual ficaria cerca de oito anos. Ele veio para o Brasil em 1859 e se estabeleceu em seus primeiros anos na cidade de São Paulo iniciando sua carreira de caricaturista como lançamento de dois periódicos: Diabo Coxo (1864-1865) e Cabrião (1865-1867). Ao se mudar para o Rio de Janeiro em 1867 contribuiu como periódico Arlequim, substituído no ano seguinte por $A$ Vida Fluminense, no qual ficaria até 1871 quando então assumiu o periódico $O$ Mosquito, permanecendo neste até 1875 . No ano seguinte lançou seu principal periódico a Revista Illustrada. Na década de 1890 lançaria outro periódico Don Quixote. Sobre atrajetória artística de Agostini ver, entre outros: (BALABAN, 2009), (OLIVEIRA, 2010), (LUSTOSA, 2014).
} 
O título do quadro é "Ajustes de Conta". O primeiro homem questiona o valor pago: "Ora seu Chefe! Quatro patacas é muito pouco! Eu dei mais de 200 vivas à Monarquia, a suas...” Sua fala é cortada pela do segundo homem que também questiona o valor contraposto com o "trabalho" que ele desempenhou " $\mathrm{E}$ eu, chefe, atirei mais de 40 pedras nas vidraças, e borrei a tabuleta... etc e etc"11. A ilustração e a legenda denunciam que os monarquistas que começaram o conflito foram, na verdade, homens contratados que receberam para iniciar a confusão. Um dos homens que questiona o valor oferecido é um negro, possivelmente um escravo, já que está com os pés descalços. Outros dois estão uniformizados; ou seja, entre aqueles que receberam dinheiro poderiam estar os próprios soldados que, além de contribuir para o conflito nada fizeram para conter o empastelamento do jornal.

Além do artigo publicado na página 2, e da ilustração apresentada como abertura daquele exemplar, o jornal foi ainda mais categórico em suas afirmações. Para reforçar a acusação de cumplicidade da polícia e o ato do seu chefe, que na opinião do periódico, pagou pessoas para protestar contra a festa republicana e depredar a sede do jornal, um outro desenho foi publicado na página 8.

A imagem mostra a sede da redação do jornal A Republica com a faixa "Viva a República" numa referência à Proclamação da República Espanhola e, logo abaixo da inscrição, o nome do jornal na tabuleta. (Figura 5) Na parte superior do prédio, na sacada, está Quintino Bocaiúva, de braços cruzados e com um olhar sério, ele apenas observa a movimentação que ocorre. Na frente, alguns homens atiram pedras em direção ao prédio, o qual já está com os vidros das janelas quebrados.

A ilustração foi dividida em dois quadros, sendo que no seu centro foi colocada a figura de um homem. Do lado esquerdo está a sede do jornal, Quintino Bocaiúva, e a cena do conflito. No lado direito, quatro homens cada um representando jornais: A Nação, Semana Illustrada (que está representada por seu personagem símbolo, o Dr. Semana), Jornal da Corte e $A$ Vida Fluminense; todos estão bem vestidos, com fraques e cartolas e nas mãos eles carregam turíbulos e incensam a figura central.

Essa figura representa o chefe da polícia da Corte que não evitou o tumulto. Contribui para essa constatação a legenda da ilustração que aponta a cena que se passa como uma "Patriotada policial nos dias 27 e 28 de fev". A frase curta demonstrava que os atos patrióticos - a defesa do Império do Brasil - foram atos isolados, da polícia. O desenho reforça a mensagem do artigo em que afirmavam que a polícia "improvisou" um povo e também vai ao encontro do manifesto republicano, segundo o qual os vivas à Monarquia não partiram da população que assistia, mas apenas de um grupo de pessoas. Contudo, a ação dos policiais foi infrutífera, ou seja, resultou em um patriotada. 11 No manifesto dos republicanos consta que durante o ataque da segunda noite "aspergiram aguarrás a tabuleta da
Republica". 


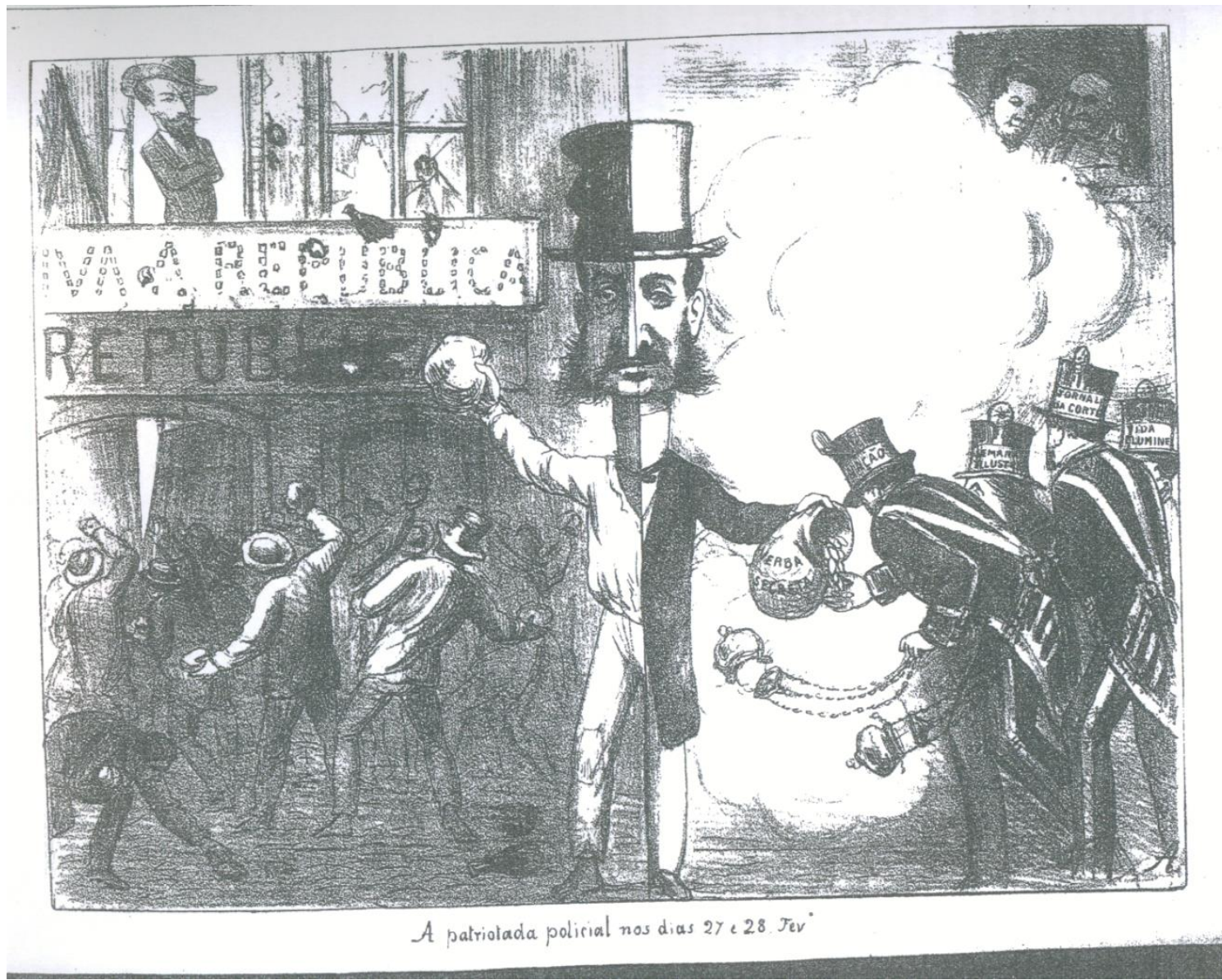

Figura 5: A patriotada policial

Legenda: A patriotada policial nos dias 27 e $28 \mathrm{fev}$.

Fonte: $O$ Mosquito, Rio de Janeiro, n.182, p.8, 08 mar. 1873. Acervo: Hemeroteca Digital-Biblioteca Nacional.

A forma como o homem foi desenhado confirma a proposta da crítica do desenho de Agostini. Ele também foi dividido: seu lado esquerdo foi desenhado com roupas mais simples, semelhante àquela dos homens que atacaram a sede do jornal e seu la do direito está com o mesmo tipo de vestimenta dos homens que representam os jornais. A partir da imagem, é possível considerar que a mensagem do jornal foi a seguinte: o homem do centro, o chefe da polícia, recebeu uma "verba secreta", conforme a inscrição no saco que carrega na sua mão direita, para se travestir em "povo" e, conforme atesta o seu lado esquerdo, possibilitar que a sede do jornal fosse depredada, situação explicitada com a pedra que ele carrega na sua mão esquerda.

Enquanto isso acontecia, os jornais, de tendências monarquistas, apenas incensavam o chefe da polícia e condenavam as atitudes republicanas, as quais, na visão de $A$ Vida Fluminense, foram as que proporcionaram o incidente. Ainda nesta imagem, no canto superior direito há duas figuras masculinas; um deles é o Visconde do Rio Branco que foi Presidente do Conselho de Ministros, pelo Partido Conservador, entre os anos de 1871 e 1875. O Presidente 
apenas observa, possivelmente de um prédio vizinho ao da República, toda a movimentação que se passava na rua; por outro lado, Agostini poderia sugerir, implicitamente, a figura do atual Presidente como o mandante de todos os atos executados.

Essa ilustração vai ao encontro das considerações que foram apontadas no artigo veiculado em $O$ Mosquito; tanto nele como na imagem as atitudes conflituosas ocorridas na sede do jornal republicano são denunciadas e sua posição é contrária aos atos de vandalismo. A imagem é antagônica a texto veiculado em $A$ Vida Fluminense, uma vez que a posição desse jornal, sobre o ocorrido, se mostrava adversa não ao vandalismo e sim à atitude comemora tiva dos republicanos. Essa posição do periódico $A$ Vida e dos demais jornais colocados na ilustração de $O$ Mosquito era um ato de incensar, encobrir (uma parte considerável da imagem está coberta por uma fumaça que sai dos turíbulos) o que estava por trás do ocorrido, ou seja, as atitudes da polícia de não combater o empastelamento ou até mesmo de encorajar e permitir que alguns homens o fizessem.

\section{A Semana Illustrada e os motins}

O terceiro jornal ilustrado do Rio de Janeiro que tratou da festa republicana foi a Semana Illustrada (1860-1876). O periódico foi fundado por Henrique Fleiuss ${ }^{12}$ e foi o primeiro que atingiu uma longevidade significativa na Corte. Ao longo dos anos de circulação angariou um número respeitável de colaboradores como os escritores Machado de Assis e Bernardo Guimarães. Além de seus próprios trabalhos litográficos, o periódico contou, em diferentes épocas, com a participa ção dos caricaturistas H. Aranha, Aristides Seelinger, Ernesto de Sousa e Silva, conhecido pelo pseudônimo Flumen Junius e Aurélio de Figueiredo (SODRÉ, 1983, p.205-206). Para compreender o posicionamento do periódico é importante levar em consideração o seu proprietário, Henrique Fleiuss.

Logo que ele se estabeleceu na Corte, em 1859, fundou com o irmão Carlos Fleiuss e com o pintor Carlos Linde um estabelecimento tipolitográfico. O estabelecimento foi uma

\footnotetext{
12 Henrique Fleiuss (1823-1882), assim como Angelo Agostini e outros caricaturistas que atuaram no Rio de Janeiro, foi outro estrangeiro que se direcionou ao Brasil no século XIX. Era umimigrante europeu nascido em Colônia em uma época em que o território alemão era formado por estados alemães ainda não unificados. Em sua cidade natal e em Dusseldorf cursou Belas Artes, além de Ciências Naturais em Munique (ANDRADE, 2011, p.53-54). Ele chegou ao Brasil em 1858, por sugestão de Carl Von Martius (1794-1868) que passou uma temporada no norte do Brasil. Fleiuss era discípulo de Martius pela sua formação em Ciências Naturais e, ao chegar ao Brasil, foi para o norte produzindo aquarelas sobre as regiões visitadas. Após o encerramento da Semana Illustrada em1876, Fleiuss fundou a revista Illustração Brasileira, inspirada em modelos de revistas norte-americanas e européias. O novo periódico, no entanto, encerraria dois anos depois do seu lançamento (AZEVEDO, 2010).
} 
iniciativa que visava suprir a carência de mão de obra especializada nas artes tipográficas e foi destinado à profissionalização de meninos carentes:

\begin{abstract}
A escola profissional ministrava cursos regulares, com duração média de três anos, de litografia, de pintura á óleo e de aquarela, de tipografia, de fotografia e de xilografia, técnica de impressão que até então não se cultivava no Brasil (GUIMARÃES, 2006, p.89).
\end{abstract}

Posteriormente, a oficina foi transformada por Dom Pedro II em Imperial Instituto Artístico. Parte dos autores que escreveram sobre a imprensa ilustrada apontou a amizade de Fleiuss com o Imperador Dom Pedro II como o motivo para o sucesso alcançado com o seu periódico. Tal relação teria se tornado explícita com a criação do Imperial Instituto Artístico.

Herman Lima salienta que devido a "vida palaciana", da qual o caricaturista desfrutava, sua arte não evoluiu e manteve-se conservadora. Ainda, avalia que a sua vida pessoal refletiuse em sua obra artística e que apesar de algumas vezes direcionar sua sátira aos "homens da política conservadora, jamais lhe permitiu incorporar-se ao grupo de demolidores do trono", grupo constituído pelos demais caricaturistas da Corte (LIMA, 1963, p.728)13. Já Luiz Teixeira, chama as relações entre Feiuss e Dom Pedro II de promíscuas e ambíguas "em todo caso sempre perigosas, entre intelectuais e poder público" (TEIXEIRA, 2001, p.10). Para Lucia Guimarães o respeito e as deferências ao Império não devem ser considerados como subservientes ao governo, e nem como uma falta de espírito crítico do caricaturista: "o lápis ágil e de ponta afiada de Henrique Fleiuss estava sempre pronto para satirizar as práticas pouco recomendadas dos políticos e das elites dirigentes" (GUIMARÃES, 2006, p.92). A partir das pesquisas realizadas nesse periódico, foi possível verificar que o direcionamento das ilustrações está mais de acordo com o que é apontado pela autora. É possível verificar nas páginas do jornal que houve um certo cuidado do caricaturista ao abordar a Família Imperial embora não significasse que críticas a determinados setores da vida política do Império não fossem realizadas no periódico. Contudo, em relação à festa republicana e aos seus desdobramentos, Fleiuss usou as páginas do seu periódico para criticar o ideário republicano.

A ilustração que foi veiculada na Semana Illustrada é semelhante àquela publicada por Agostini. Entretanto, alguns pontos permitem interpretar que a sua mensagem não é a mesma da ilustração de $O$ Mosquito. Nesta, novamente, aparece o prédio da sede da redação de A Republica. (Figura 6) Ao contrário da anterior, a faixa que constava "Viva a República" foi suprimida, mas o desenho do prédio foi enriquecido com algumas bandeiras, numa alusão àquelas colocadas pelos republicanos na fachada. Quintino Bocaiúva não aparece sozinho, ele

${ }^{13}$ A mesma posição foi verificada em: (SILVEIRA, 1996, p.38-39). 
está acompanhado por mais quatro homens e todos estão de barrete frígio; o homem do centro é Joaquim Saldanha Marinho. Naquela em $O$ Mosquito, Quintino possuía uma fisionomia séria e apenas observava a movimentação, nesta ele foi desenhado, como aquele que está um pouco atrás, com o braço erguido, respondendo às provocações vindas das pessoas que estavam na rua.

A ilustração salientou a participação popular na festa republicana, colocando alguns participantes apenas observando e outros, mais agitados, atirando objetos em direção ao prédio; para destacar o grande número de pessoas o desenho torna-se um pouco turvo, cobrindo com elas todo o espaço no entorno do prédio republicano. No caso dessa imagem, a mensagem que pode ser sugerida é a de que foi o povo, por sua livre vontade, que apedrejou A Republica e não apenas um segmento incitado pela polícia, como apontava o manifesto dos republicanos e os desenhos de $O$ Mosquito. Já os policiais não tiveram nenhuma menção na Semana. As bandeiras republicanas colocadas na fachada podem ser consideradas como o elemento que desencadeou o conflito, o que também foi apontado no texto de $A$ Vida Fluminense. 


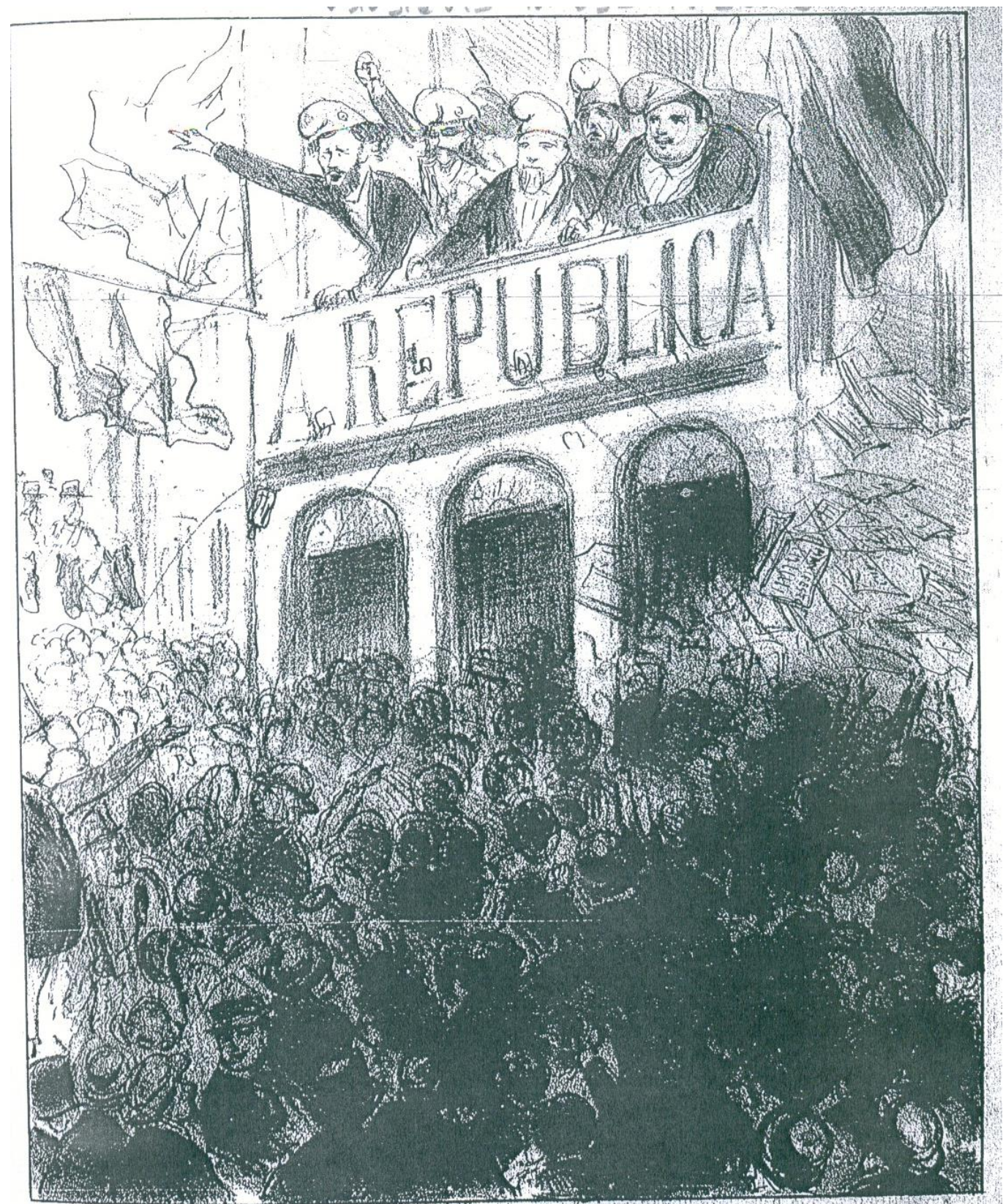

Os motins de 27 e 23 de Fevereiro

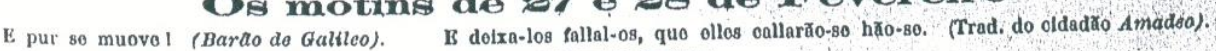

Era tamanha a algazarra,
ora tal a confusão, quo ob pesquei, á dosgarra, " concldadăos I... a notiola

"o dever l... a oplnixo l.... movo l.. herbes l... canalha l... pulhas l.. 18 aclo a Brabll l... manifestagão l.

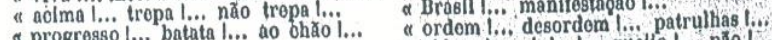
ram-tam-plăo, tamplão tamplão l.,, earne socoa com foljăo !

Figura 6: Os motins de 27 e 28 de fevereiro

Fonte: Semana Illustrada, Rio de Janeiro, n.639, p.5109, 09 mar. 1873. Acervo: Hemeroteca Digital-Biblioteca Nacional. 
Outro ponto que diferencia o desenho de Fleiuss daquele de Agostini está na legenda. Enquanto o título da ilustração veiculada em O Mosquito apresentava uma patriotada, ou seja, uma rebelião que não deu certo e que foi promovida pela polícia, o título da ilustração da Semana Illustrada travava os conflitos como motins. Ao contrário da anterior, os motins transmitem ao leitor a ideia de que foi sim o povo, sublevado, que se colocou contrário aos atos republicanos, gerando um grande tumulto e o empastelamento do jornal.

A situação era reforçada por algumas palavras que compõem os versos que narram a ação. Algazarra, confusão, desgarra, desaforo, morra, abaixo e chão passam a impressão de que o conflito se generalizou, e partiu do público que assistia. Enquanto palavras como cidadão, concidadãos, progresso, democracia e manifestação poderiam constituir o motivo que levou aos "motins". Os versos ainda reforçam que o tumulto começou a partir da fala de Quintino, chamada de um aranzel, em outras palavras, a fala enfadonha e detalhada do republicano despertou a ira do povo. Fleiuss, com esta ilustração, reforçava a defesa do Império do Brasil, talvez ameaçado pelos ventos que sopravam do outro lado do Oceano Atlântico, originados nas terras espanholas. O desenho ainda reforça o vínculo dos habitantes da corte com a Monarquia e atesta que esta é a forma de governo preferida pelo povo - manifestações contrárias ocasionam motins populares - em detrimento daquela instalada na Espanha.

A Semana Illustrada retornava aos republicanos no seu número seguinte e a crítica incluía também A Reforma. O desenho foi semelhante àquele veiculado em $A$ Vida Fluminense e reforçava a proximidade entre eles. (figura 7) Os dois jornais novamente aparecem como duas alegorias femininas, ao contrário daquelas confeccionadas por Faria, as de Fleiuss são duas mulheres mais jovens. A Republica está caída enquanto $A$ Reforma a ampara e lhe oferece uma colher de "vigor". Um balaio identificado como "roupa suja" e a sede do jornal republicano destruída, com pessoas observando, completam a ilustração. A alegoria que está em pé não foi identificada como aquela que está ao chão, conforme a inscrição na barra da saia, mas a legenda revela que se trata do jornal $A$ Reforma.

Assim como a imagem de Faria, Fleiuss se refere aos jornais como vizinhas e ainda reforça os vínculos entre os dois, colocando-os como comadres. Apesar dos esforços do jornal liberal, $A$ Republica se encontra em uma situação periclitante: "Fiz tudo quanto me foi possível para pôr-te em pé; mas perdi o meu latim. Cheiras tanto a defunto que não posso mais dar-te vigor". A resposta enfatiza que não há mais solução: "Vizinha e comadre, deixe-me morrer, embora prematuramente, não me entendereis! (...) transit res publica!”. 


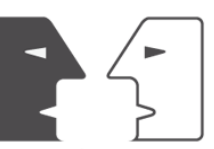

ANTÍTESES

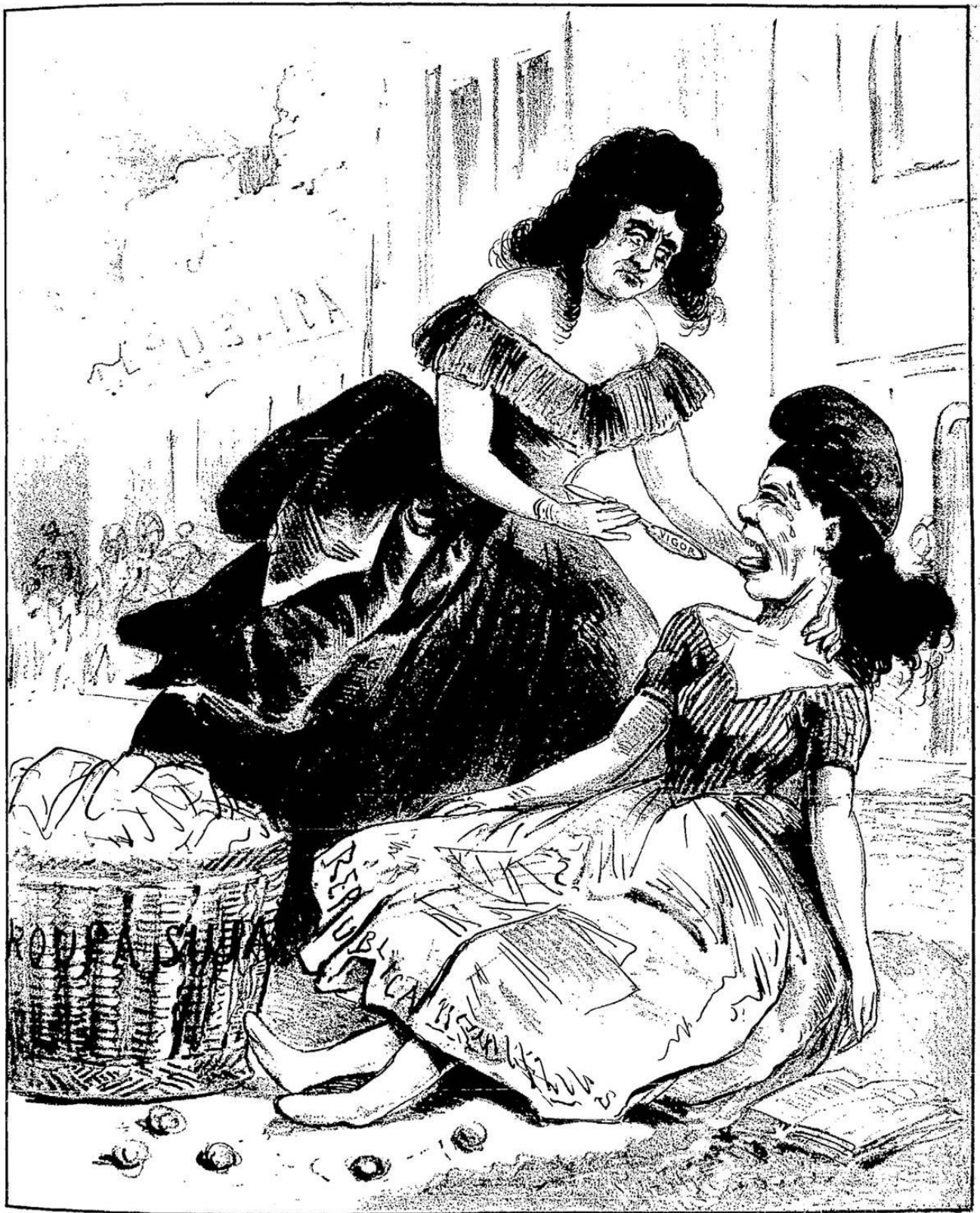

- Fiz tudo quanto me toi possivel para pôr-te em pé; ruas perdi o mell tatims. Cherrsa tanto a defunto que não posso mais dar-te vigor.

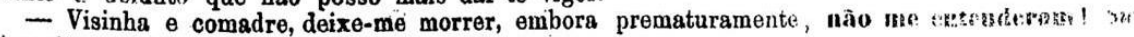
transit res publica!

Figura 7: A Republica e a colher de vigor

Legenda: - Fiz tudo quanto me foi possível para pôr-te em pé; mas perdi o meu latim. Cheiras tanto a defunto que não posso mais dar-te vigor.

- Vizinha e comadre, deixe-me morrer, embora prematuramente, não me entendereis! (...) transit res publica! Fonte: Semana Illustrada, Rio de Janeiro, n.640, p.5117, 23 mar. 1873. Acervo: Hemeroteca Digital-Biblioteca Nacional.

É possível identificar duas possíveis mensagens de Fleiuss. A primeira é semelhante àquela já verificada na ilustração anterior, ou seja, o "deixa-me morrer" pode ser uma referência ao próprio ideário republicano, o qual não teria chances de prosperar no Brasil, 
uma monarquia apoiada pelo seu povo. Ideias contrárias serão combatidas! A outra mensagem é o jornal que naqueles dias estava com sua circulação interrompida e poderia acabar morrendo. No entanto, a "previsão" do artista não se concretizou e A Republica retornava sua circulação em 15 de abril de 1873:

Os atos de agressão brutal de que foi vítima o estabelecimento da Republica nas noites de 27 e 28 de fevereiro, as ameaças individuais e a coação do terror postas em práticas pelos agentes do poder público, com um desembaraço de que não havia exemplo na nossa história política, fazem, como se vê, ineficazes para produzir o resultado que almejavam os inimigos da ideia republicana (A Republica, 15 de abril de 1873).

A polêmica causada pela festa republicana, contudo, findava nas páginas dos jornais ilustrados. A Republica, seus apoiadores e outros momentos de tensão surgiram nos anos seguintes nos periódicos. Os três periódicos encerraram suas atividades ainda nos anos 1870 e nem mesmo os seus caricaturistas presenciaram o fim da Monarquia e o surgimento da República em $1889^{14}$.

\section{Considerações finais}

Os três jornais ilustrados veicularam artigos e ilustrações que abordaram a festa dos republicanos brasileiros em regozijo à República proclamada na Espanha em 1873. A opinião não foi unânime. $A$ Vida Fluminense e Semana Illustrada apresentaram uma versão da festa e dos conflitos a partir de um ponto de vista mais crítico, em relação aos republicanos. $O$ Mosquito criticou o empastelamento do jornal, contudo sua defesa se voltou mais para a causa da imprensa e contra os atos da polícia e, dessa forma, não pode ser interpretada como uma defesa amplamente aberta dos republicanos. Contudo, a posição dos jornais, ao que tange ao ideário republicano, se transformou no decorrer dos anos. Em alguns momentos, eles poderiam veicular ilustrações críticas aos republicanos e em outros um tom amistoso era observado. Já a Semana sempre manteve um tom contrário aos republicanos. Suas ilustrações

\footnotetext{
${ }^{14}$ Faria e Agostini estavam fora do país; ambos residiam na França em 1889. Fleiuss faleceu em 15 de novembro de 1882; ironicamente no mesmo dia e no mês que sete anos depois a República seria proclamada no Brasil no lugar da Monarquia que tantas vezes foi defendida por ele no seu periódico.
} 
apresentavam um ponto vista pedagógico, dirigindo à atenção do leitor para os perigos das ideias republicanas.

Em relação aos artigos e as ilustrações sobre a festa republicana e os conflitos derivados a partir dela, não cabe desvendar se os ataques foram proporcionados pelo povo irritado com a bandeira verde e amarela sem os dísticos imperiais ou se por uma turba encabeçada por dois filhos de um senador, como era relatado no manifesto ou ainda se era um "povo", alicerçado e comandado pela polícia. O relevante é averiguar a repercussão alcançada com o festejo, a polêmica ocasionada e as suas versões transformadas em ilustrações pelos artistas e repassadas aos leitores nas páginas dos periódicos.

O ato, que a princípio nada mais era do que uma simples comemoração à inauguração de uma nova República, acabou proporcionando acaloradas discussões nos jornais e versões diferentes apontadas por eles: Monarquistas exaltados? Patriotada policial? Motins? Opiniões e versões diferentes, o que apontava para uma tomada de posição também diferente dos jornalistas e artistas. $O$ único ponto de conciliação nas imagens era a República, e nesse caso não aquela da Espanha, maso seu ideário no Brasil. Assim, vale considerar que a questão republicana, apesar de ser incipiente na década de 1870, conseguiu aparecer em alguns momentos. Um deles foi com as ocorrências de fevereiro de 1873, embora a redação tenha saído prejudicada com o empastelamento e a consequente interdição do jornal por um mês e meio, o ideário republicano, no entanto, a cabou va lorizado com as discussões no meio político e jornalístico catapultado pelo conflito. A polêmica ocorrida em 1873 foi acompanhada pelos periódicos sem que eles se descuidassem de seu objetivo principal que era causar o riso do leitor. Os textos e as ilustrações apresentavam uma visão cômica, e crítica, da política do tempo sem deixar de expressar a sua opinião e a sua versã o sobre o empastelamento.

\section{Referências}

A REFORMA. Rio de Janeiro, 1873. Hemeroteca Digital da Biblioteca Nacional/Rio de Janeiro RJ. (http://bndigital.bn.gov.br/hemeroteca-digital/)

A REPUBLICA. Rio de Janeiro, 1873. Hemeroteca Digital da Biblioteca Nacional/Rio de Janeiro RJ. (http://bndigital.bn.gov.br/hemeroteca-digital/)

A VIDA FLUMINENSE. Rio de Janeiro, 1873. Hemeroteca Digitalda Biblioteca Nacional/Rio de Janeiro-RJ. (http://bndigital.bn.gov.br/hemeroteca-digital/) 
AGULHON, Maurice. Historie Vagabonde. Etnologie et politique dans la France conteporaine. Paris: Gallimard, 1988.

AGULHON, Maurice. Marianne Au pouvoir. L'imagerie et la symbolique républicaines de 1880 à 1914. Paris: Flammarion, 1989.

ANDRADE, Joaquim Marçal Ferreira de. A trajetória de Henrique Fleiuss, da Semana Illustrada: subsídios para uma biografia. In: KNAUSS, Paulo; MALTA, Marize; OLIVEIRA, Cláudia de; VELOSO, Mônica Pimenta (Orgs.). Revistas Ilustradas. Modos de ler e ver no segundo reinado. Rio de Janeiro: Mauad X/FAPERJ, 2011, p.53-65.

AZEVEDO, Sílvia Maria. Brasil em imagens. Um estudo da revista Ilustração Brasileira (18761878). São Paulo: UNESP, 2010.

BALABAN, Marcelo. Poeta do Lápis. Sátira e política na trajetória de Angelo Agostini no Brasil Imperial (1864-1888). São Paulo: Editora da UNICAMP, 2009.

BOEHRER, George. Da Monarquia a República. História do Partido Republicano do Brasil(1870 1889). Tradução Berenice Xavier. Belo Horizonte: Itatiaia, 2000.

CAPELATO, Maria Helena Rolim. Imprensa e História do Brasil. São Paulo: Contexto, 1988.

CARVALHO. José Murilo. As conferências radicais no Rio de Janeiro: novo espaço de debate. In: CARVALHO, José Murilo (Org.) Nação e cidadania no Império: novos horizontes. Rio de Janeiro: Civilização Brasileira, 2007.

COSTA, Emilia Viotti da. Da Monarquia à República. Momentos decisivos. São Paulo: Editora da UNESP, 2007.

FERREIRA, Athos Damasceno. Imprensa Caricata do Rio Grande do Sul no Século XIX. Porto Alegre: Globo, 1964.

GUIMARÃES, Lúcia Maria Paschoal. Henrique Fleiuss: vida e obra de um artista prussiano na Corte (1859-1882). ArtCultura, Uberlândia, v.8, n¹2, 2006, p.85-95.

LIMA, Herman. História da caricatura no Brasil. Rio de Janeiro: José Olympio, 1963.

LUSTOSA, Isabel (Org), Agostini: obra, paixão e arte do italiano que desenhou o Brasil (1843 1910). Fundação Casa de Rui Barbosa, Rio de Janeiro, 2014.

MARTINS, Ana Luiza. Imprensa em tempos de Império. In: MARTINS, Ana Luiza; LUCA, Tania Regina de (Orgs.). História da Imprensa no Brasil. São Paulo: Contexto, 2008, p.45-80. 
MORAIS, Frederido. Cronologia das Artes Plásticas no Rio de Janeiro 1816-1994. Rio de Janeiro: Topbooks, 1995.

NETO, lira. Getúlio. 1930-1945. Do governo provisório à ditadura do estado novo. São Paulo: Companhia das Letras, 2013.

NEVES, Lúcia Maria Bastos P.; MOREL, Marco; FEREIRA, Tania Maria Bessone da C. (Orgs). História e imprensa: representações culturais e práticas de poder. Rio de Janeiro: DP\&A/FAPERJ, 2006.

O MOSQUITO. Rio de Janeiro, 1873. Hemeroteca Digital da Biblioteca Nacional/Rio de Janeiro RJ. (http://bndigital.bn.gov.br/hemeroteca-digital/)

OLIVEIRA, Gilberto Maringoni de. Angelo Agostini. A imprensa ilustrada da Corte à Capital Federal (1864-1910). São Paulo: Devir, 2010.

SALGUEIRO, Heliana Angotti. A comédia urbana: de Daumier a Porto Alegre. São Paulo: Fundação Armando Álvares Penteado, 2003.

SEMANA ILLUSTRADA. Rio de Janeiro, 1873. Hemeroteca Digital da Biblioteca Nacional/Rio de Janeiro-RJ. (http://bndigital.bn.gov.br/hemeroteca-digital/)

SILVA, Ciro. Quintino Bocaiúva, o Patriarca da República. Brasília: Editora da UnB, 1983.

SILVEIRA, Mauro César. A batalha de papel. A Guerra do Paraguai através da caricatura. Porto Alegre: L\&PM, 1996.

SODRÉ, Nelson Werneck. História da imprensa no Brasil. São Paulo: Martins Fontes, 1983.

TEIXEIRA, Luiz Guilherme Sodré. $O$ traço como texto: a história da charge no Rio de Janeiro de 1860 a 1930. Rio de Janeiro: Fundação Casa de Rui Barbosa, 2001.

TELLES, Angela Maria Cunha da Motta. Desenhando a Nação: Revistas ilustradas do Rio de Janeiro e Buenos Aires nas décadas de 1860 e 1870. Tese (Doutorado em História Social) Programa de Pós-Graduação em História Social/UFRJ, Rio de Janeiro, 2007.

TORAL, André Amaral de. Imagens em desordem. A iconografia da Guerra do Paraguai (18641870). São Paulo: Humanitas/FFLCH/USP, 2001.

VALDEÓN, Julio; PEREZ, Joseph; JULIÁ, Santos. Historia de España. Madrid: Editorial Espasa Calpe, 2003.

Recebido em 01/12/2016 - Aprovado em 29/06/2017 